Кучмсєв Олександр Олександрович доктор економічних наук, доцент, старший викладач кафедри управління та адміністрування, Відкритий міжнародний університет розвитку людини «Україна» вул. Львівська, 23, м. Київ, тел.: (093) 227-65-39, https://orcid.org/ 0000-0003-1803-6231

\title{
ОСОБЛИВОСТІ ЗАБЕЗПЕЧЕННЯ ЕКОНОМІЧНОЇ БЕЗПЕКИ ПІДПРИЕМСТВ ОПТОВОЇ ТОРГІВЛІ
}

Анотація. Мета статті полягає в аналізі стану управління ризиками на підприємствах оптової торгівлі, виявленні прогалин і недоліків, визначенні основних складових забезпечення економічної безпеки підприємств оптової торгівлі. Для розв'язання завдань дослідження були використані такі методи дослідження: аналітичний для вивчення й аналізу наукової літератури означеної проблеми, нормативних документів, офіційних сайтів в Інтернеті, а також аналізу функцій, методів та технологій комплексного забезпечення економічної безпеки підприємств оптової торгівлі; узагальнення для визначення понятійного апарату дослідження, формулювання теоретичних та практичних підходів та висновків; моделювання з метою розробки алгоритму планування роботи з управління ризиками на підприємствах оптової торгівлі; спостереження за процесом функціонування підприємств оптової торгівлі в сучасних реаліях та ін. Наукова новизна роботи полягає в розробці алгоритму планування роботи з управління ризиками на підприємствах оптової торгівлі. В статті розкрито порядок вивчення дестабілізуючих чинників і можливостей внутрішнього та зовнішнього середовищ підприємства оптової торгівлі, зокрема: спочатку пропонується визначити фактори зовнішнього та внутрішнього середовища, які впливають на підприємство та впливатимуть на нього в стратегічному періоді; потім зібрати інформацію про ці фактори; додатково оцінити отриману інформацію про кожен фактор впливу навколишнього середовища на підприємство та спрогнозувати величину можливого впливу; у результаті оцінки величини впливу кожного фактору на підприємство в стратегічному період пропонується виявити можливості та загрози зовнішнього та сильні та слабкі сторони внутрішнього середовища; в результаті ми отримаємо основу для стратегічного аналізу та розробки альтернативних стратегій. Проаналізовано методи оброблення інформації щодо виявлених ризиків на підприємствах оптової торгівлі. Зокрема, в залежності від ситуації, обробку інформації пропонується здійснювати такими методами: методи прогнозування (екстраполяція, множинна регресія, побудова кривої тренду, метод розробки сценаріїв, метод Дельфі, асимптотичний аналіз, аналіз 
втрат і можливостей), методи моделювання. (розробка - впровадження моделі витрат», економетрична, стохастична, кібернетична); методи оцінки впливу (аналіз прямих і перехресних впливів, дедуктивний аналіз, аналіз балансу сил тощо); експертні методи (оцінка можливого зростання та змін у ефективність напрямків стратегічного управління, метод «5х5», метод «Чотири питання», побудова матриці «ймовірність посилення фактора - його вплив на організацію» тощо). Визначено порядок можливого застосування того чи іншого виду стратегії економічної безпеки підприємств оптової торгівлі, зокрема, запропоновано застосовувати: захисну, адаптивну та пасивну стратегію. Запропоновано алгоритм планування роботи з управління ризиками на підприємствах оптової торгівлі. Визначено перспективні напрямки дослідження комплексного забезпечення економічної безпеки на підприємствах оптової торгівлі.

Ключові слова: ризик, підприємства оптової торгівлі, дестабілізуючі чинники, стратегія економічної безпеки, алгоритм планування роботи 3 управління ризиками.

Kuchmieiev Oleksandr Oleksandrovich Doctor of Economics, Associate Professor, Senior Lecturer, Department of Management and Administration, Open International University of Human Development "Ukraine" Lvivska St., 23, Kyiv, tel.: (093) 227-65-39, https://orcid.org/0000-0003-1803-6231

\section{PECULIARITIES OF ENSURING ECONOMIC SECURITY OF WHOLESALE ENTERPRISES}

Abstract. The purpose of the article is to analyze the state of risk management in wholesale enterprises, identify gaps and shortcomings, identify the main components of economic security of wholesale enterprises. The following research methods were used to solve the research tasks: analytical for studying and analyzing the scientific literature on this issue, regulations, official websites, as well as analysis of functions, methods and technologies of integrated economic security of wholesale enterprises; generalizations to determine the conceptual apparatus of research, formulation of theoretical and practical approaches and conclusions; modeling in order to develop an algorithm for planning risk management work at wholesale enterprises; observation of the process of functioning of wholesale enterprises in modern realities, etc. The scientific novelty of the work is to develop an algorithm for planning work on risk management in wholesale enterprises. The article reveals the procedure for studying the destabilizing factors and opportunities of internal and external environments of the wholesale enterprise, in particular: first, it is proposed to identify factors of external and internal environment that affect the company and will affect it in the strategic period; then gather information about these factors; additionally evaluate the received information about each factor of environmental 
impact on the enterprise and predict the magnitude of the possible impact; as a result of assessing the magnitude of the impact of each factor on the enterprise in the strategic period, it is proposed to identify opportunities and threats to the external and strengths and weaknesses of the internal environment; as a result, we will get a basis for strategic analysis and development of alternative strategies. Methods of processing information on identified risks at wholesale enterprises are analyzed. In particular, depending on the situation, information processing is proposed to be carried out by the following methods: forecasting methods (extrapolation, multiple regression, trend curve construction, scenario development method, Delphi method, asymptotic analysis, loss and opportunity analysis), modeling methods. (development - implementation of the cost model ", econometric, stochastic, cybernetic); methods of impact assessment (analysis of direct and cross-effects, deductive analysis, balance of power analysis, etc.); expert methods (assessment of possible growth and changes in the effectiveness of strategic management, the method of "5x5", the method of "Four Questions", building a matrix "the probability of strengthening the factor - its impact on the organization", etc.). The order of possible application of one or another type of strategy of economic security of wholesale trade enterprises is determined, in particular, it is offered to apply: protective, adaptive and passive strategy. An algorithm for planning risk management work at wholesale enterprises is proposed. Perspective directions of research of complex maintenance of economic safety at the enterprises of wholesale trade are defined.

Keywords: risk, wholesale enterprises, destabilizing factors, economic security strategy, risk management planning algorithm.

Постановка проблеми. Процес забезпечення економічної безпеки підприємств оптової торгівлі є одним 3 визначальних аспектів їх успішної діяльності; йому притаманна низка специфічних особливостей у залежності від обсягу, виду діяльності, забезпеченості фінансовими ресурсами, активності інноваційно - інвестиційної та зовнішньоекономічної діяльності, кількості та фаховості персоналу кожного підприємства. Домінантність цього процесу зумовлює необхідність комплексного підходу до здійснення забезпечення економічної безпеки, що дозволяє розробити їі адекватну систему, визначити та врахувати вплив дестабілізуючих чинників внутрішнього i зовнішнього середовищ, використати можливості, які створюються цими середовищами, для досягнення інтересів суб'єкта господарювання.

Результат ефективного комплексного забезпечення економічної безпеки підприємств оптової торгівлі зумовлює отримання економічного ефекту для вищезазначених підприємств. Таким чином, дослідження вищезазначеного питання є достатньо актуальним в ринкових умовах.

Аналіз останніх досліджень і публікацій. Дослідженням процесу забезпечення економічної безпеки з урахуванням особливостей впливу загроз 
та галузевої приналежності суб'єктів господарювання присвячені праці низки вітчизняних та закордонних науковців, зокрема: В.Г. Алькеми [1]; В.А. Боровкової [2]; Я.Ю. Білоуса [3]; З.Б. Живко [4]; А.Ю. Кияшко [5]; H.I. Машиної [6]; Тужилкіної О.В. [7] та інших.

Віддаючи належне науковцям, результати досліджень яких сприяли становленню економічної безпеки підприємств як науки, доцільно зазначити, що нині відсутній універсальний підхід до здійснення комплексного забезпечення економічної безпеки підприємств загалом та підприємств оптової торгівлі зокрема.

Не вирішеними раніше частини загальної проблеми $\epsilon$ те, що процес забезпечення економічної безпеки, який здійснюється на підприємствах оптової торгівлі, не завжди адекватний до існуючих потреб, особливо у сфері виявлення, попередження, оцінювання та протидії впливу дестабілізуючих чинників і залучення необхідних суб’єктів. Наукова проблема полягає у необхідності розроблення основних складових комплексного забезпечення економічної безпеки підприємств оптової торгівлі 3 урахуванням впливу дестабілізуючих чинників мікро - та макрорівнів.

Мета статті - полягає в аналізі стану управління ризиками на підприємствах оптової торгівлі, виявленні прогалин і недоліків, визначенні основних складових комплексного забезпечення економічної безпеки підприємств оптової торгівлі та розробці алгоритму планування роботи 3 управління ризиками на вищезазначених підприємствах.

Виклад основного матеріалу. Весь процес комплексного забезпечення економічної безпеки підприємств оптової торгівлі (далі - ЕБПОТ) побудований на їх діяльності із виявлення проявів дестабілізуючих чинників та розроблення заходів їх ліквідації, мінімізації впливу чи попередження настання.

У зв'язку з цим вихідною компонентою є діяльність суб'єктів забезпечення ЕБПОТ. Вони формують концепцію ЕБПОТ, в якій чітко здійснюється розподіл функцій між ними та формується перелік цілей, які передбачено досягнути у процесі реалізації зазначених функцій.

Робота суб'єктів із комплексного забезпечення ЕБПОТ розпочинається із збору інформації та діагностики впливу дестабілізуючих чинників і можливостей, які створюють внутрішнє та зовнішнє середовища.

Комплексне забезпечення ЕБПОТ потребує грунтовного інформаційного забезпечення з метою оцінювання стану внутрішнього і зовнішнього середовищ та прийняття рішень на відповідному рівні в інтересах функціонування підприємства, а також з метою зниження рівня невизначеності.

Логіка вивчення дестабілізуючих чинників і можливостей внутрішнього та зовнішнього середовищ підприємства оптової торгівлі така:

а) спочатку визначають (роблять перелік) факторів зовнішнього i внутрішнього середовищ, що впливають на підприємство і будуть мати вплив на нього у стратегічному періоді; 
б) потім збирають інформацію про ці фактори;

в) далі оцінюють отриману інформацію про кожний фактор впливу середовища на підприємство і прогнозують величину можливого впливу;

г) результатом оцінювання величини впливу кожного фактора на підприємство у стратегічному періоді $є$ визначення можливостей i загроз зовнішнього та сильних і слабких сторін внутрішнього середовищ;

д) як підсумок отримуємо базу для стратегічного аналізу і вироблення альтернативних стратегій [3, с. 245].

Вивчення стану та перспектив розвитку окремих чинників середовищ базується на збиранні якісної та кількісної інформації, іiі теоретичної або експертної обробки та формуванні відповідних аналітичних висновків. Інформаційною базою проведення дослідження $\epsilon$ зведена статистична звітність, макроекономічні дослідження, огляди кон'юнктури окремих ринків, аналітичні огляди, опубліковані в спеціальних економічних виданнях та періодичній пресі, результати вибіркових досліджень та спостережень, вивчення точок зору спеціалістів підприємства оптової торгівлі та зовнішніх фахівців, проведення зборів та обговорень тощо [5].

Оброблення інформації може відбуватися наступними методами:

1) методи прогнозування (екстраполяції, множинної регресії, побудови кривої тренду, метод розробки сценаріїв, метод «Дельфі», асимптотичний аналіз, аналіз втрат та можливостей), які застосовуються для визначення перспективних тенденцій, для виявлення майбутніх суттєвих змінних та для передбачення майбутніх подій на підставі узагальнення аналізу реальної ситуації, іiі прогнозування на майбутнє;

2) методи моделювання (розробки моделей „витрати-реалізація", економетричної, стохастичної, кібернетичної) дозволяють побудувати таку модель сучасних процесів на торгівельних підприємствах, яка дає змогу спеціалістові з планування отримувати різноманітні варіанти майбутнього, змінюючи вхідні параметри та функції змінних у рамках цієї моделі;

3) методи оцінки наслідків (аналіз прямого та перехресного впливів, дедуктивний аналіз, аналіз балансу зацікавлених сил тощо). Застосування цих методів дозволяє оцінити наслідки впливу очікуваних змін зовнішнього середовища на життєдіяльність підприємства і результати його господарсько фінансової діяльності, визначити ступінь та вірогідність одночасного настання декількох явищ.

4) експертні методи (оцінка можливого зростання та зміни ефективності стратегічних зон господарювання, метод „5х5 ", метод „чотирьох питань", побудова матриці „вірогідність посилення чинника - його вплив на організацію" тощо); їх застосування передбачає експертне формування переліку параметрів, які визначають зміни стану зовнішнього оточення та їхній вплив на діяльність підприємства, дають можливість оцінити ступінь невизначеності середовища та основні її джерела. 


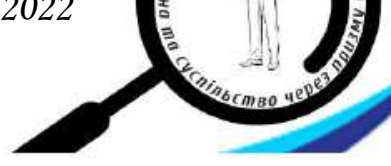

Можна стверджувати, що зазначені методи не $є$ всеохоплюючими та універсальними, доцільність їхнього застосування визначається динамікою змін та специфічністю чинників [5].

Обов'язковим елементом комплексного забезпечення ЕБПОТ є стратегія ЕБПОТ, під якою розуміють сукупність стратегічних рішень щодо реагування на зміни чинників внутрішнього та зовнішнього середовищ підприємства оптової торгівлі [7, с.38].

Серед стратегій ЕБПОТ, зважаючи на авторський підхід до визначення сутності економічної безпеки торгівельних підприємств як процесу захисту від негативних чинників впливу внутрішнього та зовнішнього середовищ, можна виокремити:

1) захисну - передбачає реалізацію ряду взаємопов'язаних заходів, спрямованих на нейтралізацію впливу дестабілізуючих чинників, умовою для їі прийняття $є$ низький рівень ЕБТП і високий рівень зовнішніх та внутрішніх загроз;

2) адаптаційну - передбачає здійснення обумовленого переліку взаємопов'язаних заходів, спрямованих на удосконалення комплексного забезпечення ЕБПОТ 3 метою підвищення рівня безпеки та недопущення реалізації загроз із найвищим рівнем впливу, умовою для іiі прийняття $\epsilon$ достатній рівень ЕБПОТ і допустимий рівень зовнішніх та внутрішніхзагроз;

3) пасивну - передбачає відслідковування змін у зовнішньому та внутрішньому середовищах, розроблення превентивних захисних заходів 3 можливістю швидкої реакції з мінімальними втратами ресурсів; умовою для піi прийняття є високий рівень ЕБПОТ і низький рівень зовнішніх та внутрішніх загроз.

Після прийняття рішення про формування стратегї ЕБПОТ виникає необхідність тактичного планування (формування організованої послідовності дій, метою яких є виконання стратегічного плану).

Важливо відзначити, що виникає додаткова необхідність здійснення оцінювання рівня ЕБПОТ за стратегічною та тактичною складовою, адже для процесу планування надзвичайно важливим $\epsilon$ наявність даних про рівень безпеки на актуальний момент часу та на перспективу.

Наступним елементом комплексного забезпечення ЕБПОТ є організування діяльності для досягнення стратегічних та тактичних цілей, що проявляється у формуванні та управлінні діяльністю системи ЕБПОТ.

Ефективного функціонування системи ЕБПОТ можна досягнути не лише за рахунок побудови їі оптимальної структури, підбору висококваліфікованого персоналу та вмілого процесу управління, але й шляхом постійного контролю за досягнутими результатами.

У зв'язку з тим, що всі заходи щодо забезпечення ЕБ на підприємстві оптової торгівлі здійснюються працівниками, актуалізується потреба мотивації праці та управління лояльністю персоналу, тому ці дії повинні бути об'єднані і 
можна їх позиціонувати як окремий елемент комплексного забезпечення ЕБПОТ.

Мотивація праці персоналу є однією із важливих компонент комплексного забезпечення ЕБПОТ. Це зумовлено тим, що саме мотивація праці виступає соціально-економічною основою поведінки та активізації зусиль персоналу торгівельного підприємства, які спрямовані на підвищення результативності діяльності і характеризує сукупність взаємопов'язаних заходів, які стимулюють окремого працівника або трудовий колектив у цілому на досягнення індивідуальних і спільних цілей діяльності підприємства [5].

На підприємстві дуже важливо правильно поєднати матеріальний та нематеріальний види мотивації, адже лише із збалансуванням їхнього співвідношення можна досягнути бажаних результатів із продуктивності праці та інших важливих показників кадрової сфери. Серед видів матеріальної мотивації можна виокремити підвищення розміру заробітної плати, заохочення преміями, створення можливості участі в капіталі тощо; серед нематеріальної можливості професійного навчання; підвищення кваліфікації; заохочення цінними подарунками; створення можливості кар'єрного росту; нагорода грамотами, відзнаками тощо. Однією із найважливіших форм нематеріальної мотивації $\epsilon$ умови виробничого середовища. До даної форми належить комфорт, зручність, а також «прийняття» робочого місця та стосунки в колективі. Комфортне оточення може вирішити багато проблем, пов'язаних зі стресом, дії якого піддається практично будь-який працівник [2, с.178].

Мотивація на торгівельному підприємстві повинна відповідати наступним вимогам: надання однакових можливостей щодо зайнятості та посадового просування за критерієм результативності праці; створення механізму, що забезпечує отримання винагороди співробітниками у безпосередній залежності від реальних результатів їх праці; узгодження рівня оплати праці 3 iï результатами та визнання особистого внеску в загальний успіх, що передбачає справедливий розподіл доходів залежно від ступеня підвищення продуктивності праці; створення належних умов для захисту здоров'я, безпеки праці та добробуту всіх працівників; підтримування в колективі атмосфери довіри, зацікавленості в реалізації загальної мети; створенні можливостей двосторонньої комунікації між керівниками та робітниками [4, с. 35].

Оптимізація системи мотивації праці персоналу на підприємстві оптової торгівлі дозволить: підвищити результативність роботи працівників; забезпечити оперативне досягнення цілей компанії; встановити взаємозв'язок результативності роботи працівників 3 оплатою i нематеріальним стимулюванням - тобто взаємозв'язок зусиль з результатом; забезпечити прозорість системи винагороди; зменшити плинність персоналу і подолати кадровий дефіцит; збалансовати бюджет для матеріального і нематеріального стимулювання; поліпшити психологічний клімат в колективі; підвищити лояльність співробітників; поліпшити результати командної роботи [6, с. 173]; 
попередити прояви виникнення дестабілізуючих чинників зі сторони персоналу.

Формування збалансованої системи мотивації праці членів трудового колективу дозволить досягнути бажаного рівня лояльності персоналу, що сприятиме підвищенню рівня безпеки підприємства у кадровій сфері.

Крім того 3 огляду на вищезазначене, вважаємо досить доречним запропонувати алгоритм планування роботи 3 управління ризиками на підприємствах оптової торгівлі ( Рис 1.). а саме:

На етапі визначення відповідальних осіб процес планування витрат на впровадження методів управління ризиками на підприємствах оптової торгівлі можна запропонувати розподілити за видами робіт і часом їх здійснення, але його результатами мають бути чітко визначені та доведені до виконавців. У зв'язку з тим, що діяльність даних торгівельних підприємств здійснюється у різних сферах ланцюга створення цінності, призначення однієї відповідальної особи не забезпечить планування усієї необхідної та релевантної інформації. Тому, з нашої точки зору, доцільно обирати відповідальних осіб за сферами виникнення ризиків: закупівлі, транспортування та реалізації продукції в роздрібну мережу.

\begin{tabular}{|c|}
\hline Визначення відповідальних осіб \\
\hline$\square$ \\
\hline $\begin{array}{l}\text { Розробка системи планів із } \\
\text { впровадження методів управління } \\
\text { ризиками за оптимістичним, базовим і } \\
\text { песимістичними сценаріями. }\end{array}$ \\
\hline$L$ \\
\hline $\begin{array}{l}\text { Розробка бюджету, призначеного для } \\
\text { управління ризиками. }\end{array}$ \\
\hline$z$ \\
\hline 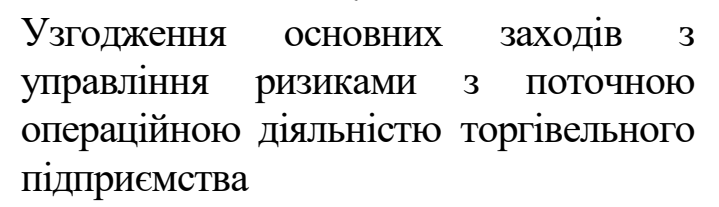 \\
\hline
\end{tabular}

Рис 1. Алгоритм планування роботи з управління ризиками на підприємствах оптової торгівлі

Джерело: укладено автором за джерелами [1; 3; 7]

Ураховуючи відсутність спеціалізованих підрозділів 3 управління ризиками на більшості підприємств оптової торгівлі, функції відповідальних 
осіб із впровадження методів управління ризиками на даних підприємствах можуть бути покладені на менеджерів відповідних підрозділів. Виконання таких функцій не потребує повної зайнятості, а отже може бути суміщено 3 іншими функціональними обов'язками.

На етапі розробки системи планів із впровадження методів управління ризиками на підприємствах оптової торгівлі за оптимістичним, базовим i песимістичним сценаріями, можна порекомендувати дотримуватись принципів загальної політики управління ризиками на підприємстві, відповідно до ставлення керівництва до ризику. Якщо політика керівництва полягає у прийнятті більшості ризикованих рішень то приймати відповідні рішення можна порекомендувати на даному етапі.

На етапі розробки бюджету, призначеного для управління ризиками на підприємствах оптової торгівлі, слід враховувати той факт, що такий бюджет суттєво впливає на вибір методів, якими доцільно користуватися для мінімізації ризиків і їх негативних наслідків.

На заключному етапі запропонованого алгоритму рекомендується узгоджувати основні заходи з управління ризиками 3 поточною операційною діяльністю підприємств оптової торгівлі.

Висновки. Результатом проведеного дослідження $є$ 3'ясування сутності поняття та специфіки комплексного забезпечення ЕБПОТ, що дозволить вітчизняним підприємствам оптової торгівлі організувати та скоординувати свої зусилля задля досягнення стабільно високого рівня ЕБ.

Крім того, розкрито порядок вивчення дестабілізуючих чинників i можливостей внутрішнього та зовнішнього середовищ підприємства оптової торгівлі; проаналізовано методи оброблення інформації щодо виявлених ризиків на підприємствах оптової торгівлі, проаналізовано порядок можливого застосування того чи іншого виду стратегії ЕБПОТ та запропоновано алгоритм планування роботи з управління ризиками на підприємствах оптової торгівлі.

До перспективних напрямів дослідження із зазначеного питання можна віднести визначення інтегрованих показників оцінки якості функціонування системи управління ризиками на підприємствах оптової торгівлі.

\section{Лimepamypa:}

1. Алькема В.Г. Система економічної безпеки логістичних утворень: [монографія] / за ред. В.Г.Алькеми. Київ : Ун-т економіки та права «КРОК», 2011. 376 с.

2. Боровкова В. А. Управление рисками в торговле. СПб. : Питер, 2014. 288 с.

3. Білоус Я.Ю. Аналіз підходів до визначення поняття «економічна безпека підприємства». Економіка Менеджмент Підприємництво, 2011. № 23 (II). C. 241-247.

4. Живко 3.Б. Стратегічне планування в системі економічної безпеки підприємства. Проблеми науки, 2012. № 4. С. 32-39.

5. Кияшко А.Ю. Мотивація праці в контексті економічної безпеки підприємства. URL: / А.Ю. Кияшко, В.В. Лойко. [Електронний ресурс]. - Режим доступу: http:// knutd.com.ua /publications/conference/20.03.2015/ Kiyashko_Lojko_11.pdf. (дата звернення: 23.09.2020) 
6. Машина Н. І. Економічний ризик і методи його вимірювання: навч. посібник. К. : ЦУЛ, 2016. 188 с.

7. Тужилкіна О.В. Підвищення вагомості нематеріальних чинників мотивації праці у формуванні людського капіталу сучасного підприємства в Україні. Актуальні проблеми економіки, 2010. № 9. С.37-41.

\section{References:}

1. Al'kema, V.G. (2011). Sistema ekonomichnoï bezpeki logistichnih utvoren' [The system of economic security of logistics entities]. Kiïv : Un-t ekonomiki ta prava «KROK» [in Ukrainian].

2. Borovkova, V. A. (2014). Upravlenie riskami v torgovle [Risk management in trade]. $\mathrm{SPb} .:$ Piter [in Russian].

3. Bilous, Ja.Ju. (2011). Analiz pidhodiv do viznachennja ponjattja «ekonomichna bezpeka pidpriemstva» [Analysis of approaches to the definition of "economic security of the enterprise"]. Ekonomika Menedzhment Pidpricmnictvo - Economics Management Entrepreneurship, 23 (II), 241-247 [in Ukrainian].

4. Zhivko, Z.B. (2012). Strategichne planuvannja v sistemi ekonomichnoï bezpeki pidpriemstva [Strategic planning in the system of economic security of the enterprise]. Problemi nauki - Problems of Science, 4, 32-39 [in Ukrainian].

5. Kijashko, A.Ju. (2020). Motivacija praci v konteksti ekonomichnoï bezpeki pidpriєmstva. [Motivation of work in the context of economic security of the enterprise]. knutd.com.ua. Retrieved from http://knutd.com.ua/publications/conference/20.03.2015/ Kiyashko_Lojko_11.pdf [in Ukrainian].

6. Mashina, N. I. (2016). Ekonomichnij rizik i metodi jogo vimirjuvannja [Economic risk and methods of measuring it]. K. : CUL [in Ukrainian].

7. Tuzhilkina, O.V. (2010). Pidvishhennja vagomosti nematerial'nih chinnikiv motivaciï praci u formuvanni ljuds'kogo kapitalu suchasnogo pidpriemstva v Ukraïni [Increasing the importance of intangible factors of work motivation in the formation of human capital of modern enterprises in Ukraine]. Aktual'ni problemi ekonomiki-Actual problems of economy, 9, 37-41 [in Ukrainian]. 